\title{
Extent of Compliance of Ethics of the Teaching Profession by Secondary School Teachers in Bayelsa State, Nigeria
}

\author{
Dr Allen A. Agih \\ Dept of Educational Foundations, Faculty of Education \\ Niger Delta University, Wilberforce Island, Bayelsa State, Nigeria \\ Email: agihallen@yahoo.com
}

\author{
Doi:10.5901/ajis.2013.v2n3p41
}

\section{Abstract}

The teaching profession in Nigeria was before now an all-comers job until 1993 when the Teachers' Registration Council of Nigeria (TRCN) Act was promulgated to professionalize it. From the period that the TRCN was established to regulate the profession, most of the members are yet to imbibe the new culture of the trade as contained in the Teachers' Code of Conduct document. This study was therefore conducted to assess the level of familiarity and compliance on some of the basic ethics of the teaching profession by Principals and teachers in the secondary schools in Bayelsa state. Data for the study were the Teachers' Code of Conduct document of the TRCN (2005) and a questionnaire on the, "Compliance Order of Secondary School Principals and Teachers (COSSPT) developed by the researcher. A sample of 1,980 (80 Principals and 1,900 teachers) representing $50 \%$ of Principals and teachers were selected from a population of 3,960. Three research questions were developed for the study. Findings revealed that the Principals were quite familiar and comply with some of the acts adjudged to be misconduct in the profession. However, the teachers do not show the same acceptable level of familiarity and compliance on the same issues that were used to assess the Principals. On the basis of the findings, some recommendations were made.

Keywords: Compliance; ethics; code of conduct; teaching; profession; secondary education.

\section{Introduction}

Until 1993 teaching was an all-comers job in Nigeria. This was because there was no regulatory agency for membership and practice as the Legal Council does for Lawyers, Council for the Regulation of Engineers (COREN) for engineers and the Nigerian Medical Association for Medical Doctors. In 1993, the Teachers Registration Council of Nigeria (TRCN) was established by Act No. 31 of 1993. This development was brought about by a rapid transformation of the teaching profession to the highest standard possible. This is particularly with respect to the quality of teacher education programmes, registration and licensing, professional conduct, and the overall status of teachers at all levels of the education system.

The question of whether teaching really is a profession or not has therefore long been settled with the enactment of the TRCN Act in Nigeria. Furthermore, the basic characteristics of a profession for which the teaching profession is one, and documented by the Association for Educational Communication and Technology (AECT), (1977) are as follows:

- An organized body of specialized knowledge constantly expanding by research;

- An intellectual technique;

- An application of that technique to practical affairs;

- A long period of training and certification;

- A series of standards and a statement of ethics which is enforced;

- The ability to exercise its own leadership;

- An association of members of the profession into a closely knit group with a high quality of communications among members;

- Acknowledgment as a profession;

- Professional concern for responsible use of its work; and

- An established relationship with other professions.

Accordingly, Awotua-Efebo (1999) remarked that there was no doubt that teaching has met all the basic characteristics of a profession going by the Association for Educational Communication and Technology (AECT), (1977) guidelines. In the same vein, Anderson (1989); Clark (1995) and Claxton (1990) have all recognized teaching as a 
profession in most of their expositions. Furthermore, the National Policy on Education (2004) has clearly recognized teaching as a profession in Section 8(B) where it stated that:

a) Since no education system can rise above the quality of its teachers, teacher education shall continue to be given major emphasis in all educational planning and development.

b) The goals of teacher education shall be:

(i) Produce highly motivated, conscientious and efficient classroom teachers for all levels of our educational system;

(ii) Encourage further the spirit of enquiry and creativity in teachers;

(iii) Help teachers to fit into the social life of the community and the society at large, and enhance their commitment to national goals.

(iv) Provide teachers with the intellectual and professional background adequate for their assignment and make them adaptable to changing situations; and

(v) Enhance teachers' commitment to the teaching profession.

From the foregoing, it is expected that the teaching profession must be guided by certain ethical principles as required by law. Ethical principles or code of ethics are conceptualized here as general guidelines, ideals or expectations that need to be taken into account, along with other relevant conditions and circumstances, in the design and analysis of teaching. They contain detailed provisions for preventing one teacher from undermining another and for preventing conflicts among them. It also contains areas of conflict between teachers and students. The goal is to promote mutual beneficial relationship among teachers and between the teachers and students, and for the development of the profession.

Given the professional status of the teaching profession, the TRCN (2005) has developed a Teachers' Code of Conduct to guide members. The document has the following objectives:

(a) To re-awaken the sense of self-esteem, quality, honour, selfless service and moral rectitude in the teacher.

(b) Protect the teacher's age-long position of nobility and leadership in the social, moral, and intellectual world.

(c) Build a strong moral foundation for the actualization of an educational system that can compete favourably in the global community.

(d) Boost public confidence in the ability of the teaching profession to regulate it and to bequeath to the nation products that are capable of making maximum contribution towards the development of the nation in particular and the world in general.

(e) Provide objective yardstick for the assessment of the teacher's conduct and discharge of professional duties. Help to guarantee the safety of the professionals and sustenance of the desired prestige of the teaching profession.

(f) Spell out the type of relationship that should exist between the teachers on one hand and severally colleagues, students and other persons who would interact with them from time to time.

(g) To clarify teacher's rights, privileges, and obligations and their legal bases.

\section{Problem of the Study}

According to the TRCN (2005), teaching has been recognized as the oldest and noblest of all professions. The reasons given were that the Engineers, Lawyers, Pharmacists, Medical Doctors and others are all made or taught by the teacher. The teaching profession has more members than any other. These are unique features that make the profession the most indomitable profession in the world. Indeed, the history of education in Nigeria shows that teachers occupied the position of great honour and influence in their communities. They epitomized integrity, knowledge, leadership, moral rectitude and selfless service. They spearheaded the development of their communities and country. But over the years things appeared to have changed for the worse. In order to maintain and restore the teacher's enviable status and qualities, there is the need to enact this code of conduct to define the minimum standards expected of professional teachers in terms of their thoughts, words and actions. Consequently, the code of conduct was produced for widest circulation among teachers and it is hoped that it will meet the yearnings and aspirations of the nation to build a veritable standard of education through dedicated, competent and dependable teaching force.

The objectives of the Teachers' Code of Conduct, as highlighted in the draft document of TRCN and also in the introductory part of this paper, are quite laudable. The TRCN also stated that the Teachers' Code of Conduct will be given wide publicity and circulation to inform and enlighten teachers on the do's and don'ts of the profession. The Teachers' Code of Conduct is relatively new in coming when compared with those of the other professions. There is therefore, the 
need for an assessment of the compliance order of the Teachers' Code of Conduct in the schools so far. This is so because the goal of the Council as earlier stated is to transform the teaching profession to the highest standard possible with respect to quality of teacher education programmes, registration and licensing, mandatory continuing professional development, professional conduct, and overall social status of teachers at all levels of the education system.

This study was therefore conducted to find out the extent of teachers' compliance with the ethics of the teaching profession, with particular reference to acts adjudged to be misconduct of members (teachers) in the secondary schools in Bayelsa State. The relevance of the study is that, without the required fundamental change in the attitudes, values, ideals, orientation and practices as obtained in the other professions, the desired transformation of the education system may not be achieved.

\section{Purpose of the Study}

The purpose of the study was to find out the extent of compliance by teachers in the secondary schools in Bayelsa State on the ethics of the profession. Specifically, the study tried to assess:

i. The major ethics of the teaching profession in secondary education

ii. The familiarity of teachers with the ethics of the profession.

iii. How well teachers comply with the ethics of the profession.

\section{Research Questions}

1. What are the major ethics of the teaching profession in the secondary school?

2. How familiar are the secondary school teachers with the ethics of the teaching profession?

3. How well do the teachers comply with the ethics of the profession?

\section{Methodology}

The sources of data for this study were Teachers Code of Conduct document of the TRCN (2005) and a questionnaire on, "Compliance Order of Secondary School Principals and Teachers (COSSPT)," developed by the researcher. One thousand nine hundred and eighty $(1,980)$, made up of 80 principals and 1900 teachers, which represented $50 \%$ of principals and teachers were sampled from a population of 3,960 (Post Primary Education Board, Bayelsa State, 2011). Three research questions were developed for the study. Data were analysed using frequencies, percentages and bar chart. To be able to obtain objective assessment of participants' levels of familiarity and compliance, the principals were made to assess the teachers, while the teachers rated their principals on the various items.

\section{Results}

Out of the twenty-one items listed in the Teachers Code of Conduct in the TRCN (2005) document, only twelve of them, which represented the major acts adjudged to be misconducts in the secondary schools, were utilized for the study. Table 1 and figures 1 and 2 present the data analysed on the familiarity and compliance level of principals and teachers on some of the ethics of the profession.

Table 1: Ethics of Teaching Profession Indicators (Acts Adjudged to be Misconduct) Familiarity and Compliance Levels.

\begin{tabular}{|c|c|c|c|c|c|c|c|c|c|}
\hline \multirow{3}{*}{$\mathrm{S} / \mathrm{N}$} & \multirow{3}{*}{ Acts of Misconduct Indicators } & \multicolumn{4}{|c|}{\begin{tabular}{|c|} 
Level of \\
Familiarity (No. \& \%) \\
\end{tabular}} & \multicolumn{4}{|c|}{ Level of Compliance (No. \& \%) } \\
\hline & & \multicolumn{2}{|c|}{ Principals } & \multicolumn{2}{|c|}{ Teachers } & \multicolumn{2}{|c|}{ Principals } & \multicolumn{2}{|c|}{ Teachers } \\
\hline & & No & $\%$ & No. & $\%$ & No & $\%$ & No. & $\%$ \\
\hline 1. & Forgery or mutilation of official document & 78 & 97.5 & 1760 & 92.6 & 56 & 70 & 1672 & 88 \\
\hline 2. & Fighting in or within the school premises & 77 & 96.3 & 1520 & 80 & 79 & 98.8 & 1720 & 90.5 \\
\hline 3. & Assaulting a student or teacher & 68 & 85 & 74 & 38.9 & 64 & 80 & 82 & 43.2 \\
\hline 4. & Intimidation of student(s) & 59 & 73.8 & 65 & 34.2 & 37 & 46.3 & 54 & 16.3 \\
\hline 5. & Absenteeism & 54 & 67.5 & 55 & 28.9 & 49 & 61.3 & 48 & 17.9 \\
\hline 6. & Taking undue advantages of students or teachers & 48 & 60 & 43 & 22.6 & 31 & 38.8 & 45 & 16.8 \\
\hline 7. & Facilitating, aiding, abetting or assessor to exam malpractice & 79 & 98.8 & 1820 & 95.8 & 57 & 71.3 & 56 & 23.2 \\
\hline
\end{tabular}




\begin{tabular}{|c|l|c|c|c|c|c|c|c|c|}
\hline 8. & Irregular or unauthorized award of marks & 67 & 83.8 & 1490 & 78.4 & 51 & 63.8 & 57 & 17.4 \\
\hline 9. & Extortion from students & 75 & 93.8 & 1870 & 98.4 & 45 & 56.3 & 48 & 18.4 \\
\hline 10. & Money for marks racket & 78 & 97.5 & 1709 & 89.9 & 59 & 73.8 & 56 & 22.1 \\
\hline 11. & Teaching with non-qualifying or unrecognized certificates & 65 & 81.3 & 1540 & 81.1 & 63 & 78.8 & 44 & 15.8 \\
\hline 12. & Teaching without registration with TRCN & 53 & 66.3 & 54 & 28.4 & 48 & 60 & 41 & 14.7 \\
\hline
\end{tabular}

Figure 1: Percentage Analysis of Ethics of Teaching Profession Indicators (Acts Adjudged to be Misconduct) Familiarity Level.

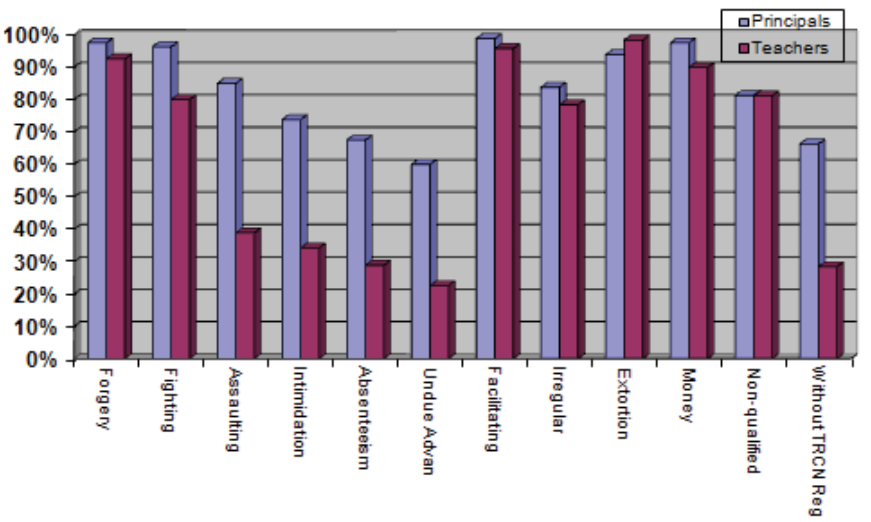

Figure 2: Percentage Analysis of Ethics of Teaching Profession Indicators (Acts Adjudged to be Misconduct) Compliance Level.

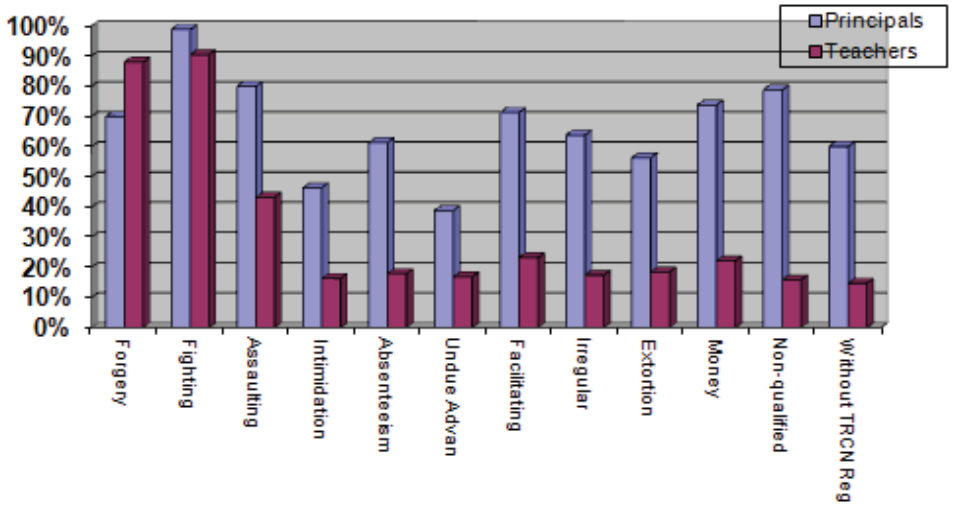

The level of familiarity of principals and teachers on acts adjudged to be misconducts are shown in table 1 and figure 1. Evidence revealed that the principals were more familiar with the acts adjudged to be misconduct in the teaching profession as shown from the percentage analysis. The least item, which was taking undue advantages of students or teachers, recorded $60 \%$. This is equally clearly shown in figure 1 . However, the teachers did not display similar level of familiarity on the ethics of the profession like the principals. This is also revealed from the table and graphic analyses with some poor familiarity level ranging from $28.4 \%$ to $38.9 \%$.

Results of the level of compliance by the principals and teachers of the acts adjudged to be misconduct in the teaching profession were equally shown in table 1 and figure 2. Findings revealed that there is an appreciable level of compliance on the part of the principals. The least recorded percentages were on intimidation of students (46.3\%), and taking undue advantages of students and teachers (38.8\%). This gives them $83.3 \%$ compliance level. However, the compliance level of teachers on the items is quite poor. On the average, they only recorded $16.7 \%$ compliance level on all the items of the study. Figure 2 graphically illustrates the compliance level of principals and teachers on the variables of the study. 


\section{Discussion of Findings}

Evidence shown from the findings indicated that there is an acceptable level of familiarity of some of the ethical issues of the teaching profession, especially on the part of the principals. However, the compliance level of principals differs with their level of familiarity on the items of study. It was poorer for the teachers with only $17 \%$ compliance level. However, the teachers recorded $58 \%$ familiarity level on the variables of the study.

These findings are quite understandable, and their reasons are not far fetched. Even though teaching qualifies to be categorized as a profession like those of Engineers, Lawyers, Medical Doctors and others, it was not so recognized with the necessary laws, until recently. In Nigeria, the TRCN, the body charged with the responsibility of regulating and licensing teachers was only made functional with Act No. 31 of 1993. When this is compared with those of the other professions like Engineers, Medical Doctors, Pharmacists and the others that have been in operation in the country for decades, then it is quite understandable why teachers exhibit poor familiarity and compliance on the ethics of the profession. The poor level of familiarity and compliance of ethics of the profession by teachers and principals in the schools is therefore quite explicable.

Also, the teaching profession has more members than any other. While the Medical Doctors, Lawyers, Engineers, Nurses and so forth are able to meet annually for their conferences, the teachers may not be able to do so because of their large number. Organizing a function for teachers has always been for certain arms, like Science Teachers Association of Nigeria (STAN), or their executive bodies like Nigerian Union of Teachers (NUT), Association of Nigerian Conference of Principals of Secondary Schools (ANCORPS) and so on.

Moreso, because of the delay in establishing the TRCN Act to regulate the profession, teaching had before now been an all-comers job. Most of those who teach in the schools preferred to relate with other professional bodies they belong. For instance, the Lawyers who teach in the schools are more likely to attend the Nigerian Bar Association Conference than a teaching related conference, if given the option. This is equally applicable to those in other professional calling.

Furthermore, production and circulation of the Teachers Code of Conduct guidelines among teachers is still very poor in the country. Most teachers do not have a copy of the Teachers Code of Conduct guideline. A good number do not even know that such a document exists. The question then is: How and what will guide their professional conduct in their places of work? To say the least, even during their training in the education institutions, enough emphasis is not usually given to student-teachers on the ethical issues of the profession. Only a few instructors may just mention them in passing, without sufficient display and discussion on the ethical issues of the profession.

Generally, the poor compliance of the ethical items of the study by participants, especially the teachers suggests poor moral character of teachers in the schools. The poor ethical behaviour of teachers has had serious consequences in the profession, and in the moral upbringing of students in the schools. This is clearly shown in the way of life of most children, which is characterized by lack of respect, dishonesty, impatience and so on. The rampant cases of cultism and other delinquent behaviours in the schools are traceable to this.

Remarking on the importance of exhibiting exemplary ethical principles in life, Peale (1938), observed that this world is somehow built on moral foundations. Iheoma (1995) equally agreed to this fact in his remark that:

\footnotetext{
...what matters most to a nation's well being is its spiritual and moral health. Everything else which a nation strives for depends on this - whether it is national integration, political stability, economic development, or educational, scientific and technological progress. Nigeria is a country that is morally and spiritually sick. A basic aim of moral education in Nigerian schools must be to restore sanity to the nation's way of life through, discipline, respect and concern for others, justice and devotion to duty.
}

All these go to affirm the importance of ethical principles, which border on the moral health of a people. Succeeding nations, associations and people are those that their leaders and followers exemplarify the age old virtues of honesty, humility, truthfulness, co-operation, responsibility, patience, transparency, which are generally code of conduct for healthy association and living.

\section{Conclusion/Recommendations}

The teaching profession, just like the others in Engineering, Law, Pharmacy, and the others is guided by certain does and don'ts. These dos and don'ts are regarded as ethical principles that guide professional conduct of members for effective service delivery, reputation and respect for the profession. While the other professions have been guided by ethical 
principles through legislation over the years, that of teachers in Nigeria was newly enacted into law in 1993, with the TRCN Act No. 31 of 1993. It was therefore, necessary to conduct a study to assess the familiarity and compliance level of some of the code of conduct issues of the profession by secondary school teachers in Bayelsa State. Findings revealed appreciable familiarity and compliance level of some of the Code of Conduct issues by the principals, but with dismal awareness and compliance by the teachers.

Arising from the findings, it would be necessary to recommend that periodic workshops, conferences and seminars be organized for teachers. This can be done in order of the six geopolitical zones in the country. The minimum National Certificate of Education (NCE) requirement for teaching should be enforced to encourage professionalism. Registration and licensing of teachers should be done in the teaching institutions for students before graduation. This is done in most of the tertiary institutions, and the practice is quite laudable. Practicing teachers who have not registered and are teaching should be given time frame to register, while those teaching without the necessary qualification should be encouraged to undergo a post graduate diploma programme in Education from recognized institutions and be made to register with TRCN. This will engender professionalism and effectiveness among teachers. Also the TRCN should produce and widely circulate the Teachers Code of Conduct booklets to all teachers in the country. Student-teachers while still in school should be properly instructed on the Teachers Code of Conduct like the other professions. One way to achieve this would be to design a course for instruction on Teachers Code of Conduct as a compulsory course of study for student-teachers in all teaching institutions in Nigeria. Finally, the Teachers Salary Scale (TSS) should be implemented by the government. This will encourage those who have not yet registered to do so. It is equally one way to truly give professional status to teachers in Nigeria.

\section{References}

AECT (1977). Association for Educational Communication and Technology: A Glossary of Terms. Washington, D.C: AECT. Anderson, L. W. (1989). The Effective Teacher Study Guide and Readings. New York: Random House Awotua-Efebo, E.B. (1999). Effective Teaching and Learning Techniques: Port Harcourt: Paragraphics. Clark, M. C. (1995). Thoughtful Teaching. London: Cassell Claxton, G. (1990). Teaching to Learn: A Direction for Education. London: Cassell. Federal Government of Nigeria (2004). National Policy on Education. Abuja: NERC. Iheoma, E. O. (1995). Moral Education for Colleges and Universities. Enugu: Fourth Dimension Publishers. Peale, N.V. (1938). You Can Win. New York: Abingdon- Cokesbury Press. Teachers Registration Council of Nigeria (2005). Teachers' Code of Conduct. Abuja: TRCN. 